\title{
THE EFFECT OF RENEWABLE AND FOSSIL FUEL ENERGY CONSUMPTION ON TOTAL FACTOR PRODUCTIVITY IN G20 COUNTRIES*
}

\section{G20 Ülkelerinde Yenilenebilir ve Fosil Yakıt Enerji Tüketiminin Toplam Faktör Verimliliği Üzerindeki Etkisi}

\section{Buket ALTINÖZ**}

\begin{abstract}
The aim of this study is to examine the effect of both renewable and fossil fuel energy consumption on total factor productivity in G20 countries by using

Keywords:

Total Factor

Productivity,

Energy,

Panel Data,

Cointegration.

JEL Codes:

D24, O13, C23

fixed effects with Driscoll and Kraay standard errors approach. Analysis results suggest that renewable energy consumption has a positive impact on total factor productivity in the long run. Accordingly, an increase in renewable energy consumption increases the total factor productivity by about 0.007 percent in the long run. Although the coefficient of fossil fuel energy consumption is positive, it is statistically insignificant. In this study, labor force and capital are included in model as control variables. While capital formation increases total factor productivity in the long run, total labor force decreases it. The results highlight the necessity of including renewable energy consumption and capital accumulation in possible policies to increase total factor productivity. Moreover, revising energy consumption policies to encourage renewable sources may be one of the priorities of policymakers to increase the positive impact of renewable energy consumption.
\end{abstract}

Anahtar Kelimeler:

Toplam Faktör

Verimliliği,

Enerji,

Panel Veri,

Eşbütünleşme.

JEL Codes:

D24, O13, C23

\section{$\ddot{O} \mathbf{z}$}

Bu çalışmanın amacı Driscoll ve Kraay standart hatalar yaklaşımı ile sabit etkiler yöntemini kullanarak G20 ülkelerinde hem yenilenebilir hem de fosil yakıt enerji tüketiminin toplam faktör verimliliği üzerindeki etkisini incelemektir. Analiz sonuçları, yenilenebilir enerji tüketiminin uzun vadede toplam faktör verimliliği üzerinde olumlu bir etkiye sahip olduğunu göstermektedir. Buna göre, yenilenebilir enerji tüketimindeki bir artış, uzun vadede toplam faktör verimliliğini yaklaşık yüzde 0.007 oranında artırmaktadır. Fosil yakıt enerji tüketimi katsayısı pozitif olmasına rağmen istatistiksel olarak anlamsızdır. Bu çalışmada işgücü ve sermaye kontrol değişkenler olarak modele dahil edilmiştir. Uzun dönemde brüt sermaye oluşumu toplam faktör verimliliğini artırırken, toplam işgücü azaltıcı bir etkiye sahiptir. Sonuçlar, toplam faktör verimliliğini artırmak için olası politikalara yenilenebilir enerji tüketimi ve sermaye birikiminin dahil edilmesinin gerekliliğini vurgulamaktadır. Ayrıca, enerji tüketim politikalarının yenilenebilir kaynakları teşvik edecek şekilde revize edilmesi, yenilenebilir enerji tüketiminin olumlu etkisini artırmak için politika yapıcıların önceliklerinden biri olabilir.

\footnotetext{
* This is the revised and edited version of the paper presented at the 5th International Conference on Economics Research and Financial Markets Congress (IERFM).

** Dr., Nişantaşı University, Vocational School, buket.altinoz@nisantasi.edu.tr, ORCID: 000-0002-42764821
}

Makale Geliş Tarihi (Received Date): 09.11.2021 Makale Kabul Tarihi (Accepted Date): 26.12.2021 


\section{Introduction}

Energy is accepted as an indispensable element in the economic and social development of countries and in increasing welfare. This importance of energy leads to the widespread inclusion of energy consumption in growth models. The relationship between energy consumption and economic growth is discussed by many studies in the literature (Ouedraogo, 2013; Ozcan and Ozturk, 2019; Shahbaz, Zkaria, Shahzad and Mahalik, 2018; Wang and Lee, 2021). Studies on the energy consumption and growth nexus focus on four basic hypotheses: growth hypothesis, conservation hypothesis, neutrality hypothesis, and feedback hypothesis. The growth hypothesis is based on a unidirectional causality from energy to economic growth. The opposite defines the conservation hypothesis. The bidirectional causality between energy consumption and growth corresponds to the feedback hypothesis. Finally, the neutrality hypothesis states that energy consumption is relatively smaller in the economic growth process (Ocal and Aslan, 2013).

Recently, the relationship between energy use and total factor productivity (TFP) has been studied in the related literature (Rath, Akram, Bal and Mahalik, 2019; Sohag, Chukayina and Samargandi, 2021; Tugcu, 2013 etc.). Total factor productivity is known as an element of welfare and long run growth. Total factor productivity usually comes to the fore with its contribution to the increase in welfare. Therefore, determining the factors affecting the total factor productivity gains importance in ensuring the increase in welfare through these factors (Isaksson, 2007). This study focuses on the effect of energy consumption on total factor productivity. The literature on this nexus is relatively new. In addition, there is no consensus in the conclusions reached regarding the relationship between energy consumption and TFP.

Total factor productivity is simply defined as the ratio of the total input to total output. In the literature examining the relationship between energy consumption and output, two concepts, energy density, and energy efficiency, are generally used (Şimşek, 2011, p. 379). The sustainability of economic output is largely linked to energy efficiency. At this point, sustainable, renewable, and environmentally friendly energy sources gain importance. Therefore, both saving energy and expanding the energy consumption with low carbon emissions are a driving force for improvement in total factor productivity.

Today, as in many fields, the general opinion in the context of energy regarding TFP is that the increasing trend towards renewable energy consumption from fossil fuel energy consumption increases TFP (Rahman, Shahari, Rahman and Noman, 2017; Rath et al., 2019). Primarily, such a process in the energy consumption of countries affects TFP through the dissemination of renewable energy technologies. Accordingly, the development of such technologies increases the employment of skilled labor, and the use of new technologies enables the increase in international competition, labor mobility, new investments, and projects to enter the country. In addition, as the use of environmentally friendly energy becomes more widespread, the vulnerability of countries to fluctuations in oil prices is greatly reduced. Moreover, the use of renewable energy consumption, due to contributes environmental sustainability, increases labor productivity, and helps protect natural resources. Thus, TFP growth is supported (Sohag et al., 2021; Şimşek, 2011). In the light of these explanations, the TFP effect, which arises as a result of the economic and environmental effects caused by energy types in the relationship between energy consumption and TFP, draws attention to the importance of the energy compositions of countries for TFP. 
Studies in the literature suggest that the effects of energy consumption on TFP should be considered. However, investigating this effect according to different types of energy rather than total energy consumption provides more beneficial results in terms of policy-making processes. From this point of view, this study discusses the role of both fossil fuel and renewable energy consumption in TFP growth in G20 countries for the period from 1990 to 2015 . This study makes some contributions to the related literature. First, while the relevant literature focused more heavily on the energy-growth, the studies focused on the energy-TFP link are relatively limited. Moreover, there is no consensus yet in this limited literature investigating the energyTFP nexus. Therefore, it has become necessary to both contribute to the developing literature on this subject and present new evidence on the effect of energy consumption on TFP. This study is an effort to address this need in the literature. Second, in this study, the relationship between energy consumption and TFP is discussed for the first time for G20 countries. The fact that the issue of energy has a great place on the agenda of the G20, a global forum of major economies, and that these countries have a leading role in global energy policies, makes it important to address these countries. Third, energy consumption is considered in the context of both fossil fuel and renewable energy. Thus, it is aimed both to contribute to the development of the literature and to present concrete policy implications to these countries in the context of energy type. Fourth, second generation panel unit root test, panel causality test and coefficient estimation method are used in this study. The most important reason for using these analysis techniques is the heterogeneity of the countries, especially in terms of total factor productivity indicator. For the long run relationships between energy consumption and TFP are estimated by using fixed effects with Driscoll-Kraay standard errors. This method is used for the first time to address the energy-TFP link, unlike previous literature. The advantages provided by the method offer the methodological contribution of this study. This method is important in that it is robust to diagnostic problems. Moreover, the Driscoll and Kraay standard errors of parameter estimates are obtained with the help of the square roots of the diagonal elements of the asymptotic covariance matrix. Therefore, with this approach, which is based on cross-sectional means, the standard error is consistent regardless of the cross-section size $\mathrm{N}$ of the units.

This study consists of five sections. Section 2 includes an empirical literature review. In the third part, the model adopted in this paper is introduced, the dataset is explained and information about the methodology is given. In the fourth part, the analysis results are presented. In conclusion part, policy recommendations are developed by making some inferences.

\section{Literature Review}

The relationship between energy consumption and economic growth has well-developed literature. Kraft and Kraft (1978) is a pioneering study in this field. In their study, the existence of unidirectional causality from economic growth to energy consumption has been put forward in the USA. In the following years, other studies supporting this result are also found in the literature (Aqeel and Butt, 2001; Cheng and Lai, 1997; Fang and Chang, 2016; Mehrara, 2007; Narayan and Narayan, 2010). There are also many studies that find no relationship between growth and energy consumption (Payne, 2009; Yu and Jin, 1992). In addition, studies that conclude that economic growth is a cause of energy consumption constitute another aspect of the literature (Acaravc1, Erdogan and Akalin, 2015; Dogan, 2014; Hamilton, 1983; Masih and 
Masih, 1996). Moreover, there are studies that correspond to the feedback hypothesis and detect the existence of bidirectional causality between two variables (Glasure, 2002; Nasreen and Anwar, 2014; Ouedraogo, 2013; Paul and Bhattacharya, 2004). These studies and their results show that there is ambiguous conclusion about this nexus and that there is ongoing literature.

Over time, studies that deal with the relationship between different energy indicators and growth instead of total energy consumption have taken place in the related literature. For example, Bhattacharya, Paramati, Ozturk and Bhattacharya (2016) analyzed the effect of renewable energy consumption on growth. Their results suggested that renewable energy consumption has a positive impact on economic growth. A different result was found by Isik, Dogru and Turk (2018). They suggested that there is no significant relationship between them. Chen, Pinar and Stengos (2020) found a positive effect of renewable energy consumption on growth after a certain threshold value. Baz et al. (2021) analyzed the effect of both fossil fuel and renewable energy consumption on growth in Pakistan. Their results illustrated that positive and negative shocks of these energy indicators had a neutral effect. A different result was found by Lin and $\mathrm{Xu}$ (2020). They studied for China and results suggested that there is an inverted Ushaped relationship between fossil fuel energy and growth. These studies demonstrated that segregating energy consumption by type offers important results. Therefore, this result is the reason why many studies have addressed the effect of renewable and non-renewable energy consumption on growth.

Although many studies focus on energy in the context of growth, total factor productivity is a neglected aspect in this field. Tugcu (2013) analyzed the relationship between alternative, nuclear, fossil, and renewable energy consumption and TFP in Turkey. Analysis results suggested that renewable energy consumption positively affects TFP. Ladu and Meleddu (2014) confirmed the bidirectional causality between total energy consumption and TFP. Also, they determined the positive impact of electric power consumption on TFP. Moghaddasi and Pour (2016) because energy is a critical input for the agriculture sector, analyzed the energy-TFP nexus for the Iranian agriculture sector for the period from 1974 to 2012. Their model includes total energy consumption in agriculture, which is in million barrels of crude oil, as an explanatory variable. Their results illustrated that the negative relation between TFP growth and energy consumption. Tugcu and Tiwari (2016) considered the impact of both renewable and non-renewable energy consumption on TFP separately, based on the idea that renewable energy contributes to environmental and technical efficiency. They focused on coal, nuclear energy, hydroelectricity, total renewable electricity, and total non-renewable electricity consumption as energy variables. For non-renewables, they found the unidirectional causality from coal to TFP, from TFP to nuclear energy, from nuclear energy to TFP in South Africa, and from natural gas to TFP in Brazil. Also, they revealed that there is no causality between renewable energy consumption and TFP growth in BRICS countries. Rahman et al. (2017) investigated the linkage between sectoral productivity and disaggregated energy consumption by using the Markov Switching approach in Malaysia. They used total energy, electricity, fossil fuel, natural gas, coal, and mineral energy consumption as energy variables. Their analysis results demonstrated that industrial and manufacturing productivity responds with disaggregated energy consumption. Accordingly, all energy types except fossil fuel contribute to manufacturing productivity. Rath et al. (2019) estimated the effect of renewable and fossil energy consumption on TFP in 36 countries. The sample group of this study was divided into groups as both developed and developing countries according to income levels, and European, 
Latin American, and Asian countries according to regions. Their analysis results showed that while fossil fuel energy consumption has a negative impact on TFP in the aggregate panel. More detailed, fossil fuel energy consumption mitigates TFP growth in developed countries, Latin American regions, but contributes to it in developing countries, European and Asian regions. Also, renewable energy consumption contributes to TFP growth in the aggregate panel. However, this result is invalid for African countries. Sohag et al. (2021) studied for OECD countries and reached that renewable energy positively affects TFP. Also, they included nonrenewable energy consumption in the econometric model. Accordingly, non-renewable energy consumption has no statistically significant effect on TFP.

In the light of the literature review, this study contributes to a relatively new aspect of the relevant literature by focusing on the energy-TFP nexus. In addition, it is aimed to fill a gap in the literature in terms of sample group by focusing on G20 countries.

\section{Model, Data and Methodology}

This paper analyzes the relationship between renewable and fossil fuel energy consumption and total factor productivity in G20 countries ${ }^{1}$ for the period from 1990 to $2015 .^{2}$ For this purpose, the main function inspiring by Tugcu and Tiwari (2016), Rath et al. (2019), and Sohag et al. (2021) that we have used is as follows:

$$
T F P_{i t}=f\left(F E_{i t}, R E E_{i t}, K_{i t}, L_{i t}\right)
$$

The panel equation can be written as follows:

$$
T F P_{i t}=\beta_{0}+\beta_{1} F E+\beta_{1} R E E_{i t}+\beta_{3} K_{i t}+\beta_{4} L_{i t}+\vartheta_{i t}
$$

where $i$ and $t$ denote country and data period, respectively. The dependent variable of the model TFP represents total factor productivity. Independent variables are the share of fossil fuel energy consumption in total energy consumption $(F E)$, the share of renewable energy consumption in total final energy consumption (REE), gross fixed capital formation $(K)$ and total labor force $(L)$, respectively. All independent variables are obtained from World Bank, World Development Indicators. Dependent variable obtained from Penn World Table 10.0.

In the first stage of the analysis, the stationarity test of the series is performed. Which unit root test to use is determined according to the results of the cross-sectional dependence test. For this, the cross-sectional dependency test developed by Pesaran (2004) is adopted. A secondgeneration panel unit root test is employed to determine the degree of integration of the respective variables. The Pesaran (2007) panel unit root test does not require the estimation of factor loading to eliminate cross-sectional dependence. Specifically, the usual ADF regression is augmented to include the lagged cross-sectional mean and its first difference to capture the cross-sectional dependence that arises through a single-factor model. The null hypothesis is a unit root for the Pesaran (2007), the CIPS test is specified as follows:

\footnotetext{
${ }^{1}$ Argentina, Australia, Brazil, Canada, China, France, Germany, India, Indonesia, Italy, Japan, Korea, Mexico, Russia, Saudi Arabia, South Africa, Turkey, United Kingdom, United States.

${ }^{2}$ Ethics committee approval and/or legal/special permission are not required fort his study. Also, research and publication ethics are complied with in this study.
} 


$$
\operatorname{CIPS}(N, T)=N^{-1} \sum_{\mathrm{i}=1}^{N} t_{i}(N, T)
$$

where $\operatorname{CIPS}(N, T)$ is the cross-section augmented form of the IPS unit root test developed by Im, Pesaran and Shin (2003) and ti $(N, T)$ is the cross-section augmented Dickey-Fuller statistic.

After the unit root test, the long run relationship between the variables is discussed. Westerlund (2007) cointegration test, which is a second-generation testing approach, tested whether there is a long run cointegration relationship between variables. With the determination of the cointegration relationship, the long run coefficients are estimated in the next step. For this purpose, the fixed effects regression with Driscoll and Kraay standard errors. Driscoll and Kraay (1998) proposed a nonparametric covariance matrix estimator. This method robust to autocorrelation, heteroscedasticity and cross-sectional dependency.

\section{Empirical Findings}

In the first stage of the analysis, the cross-sectional dependency test is applied, and the presence of cross-sectional dependence is determined according to the results in Table 1. Therefore, the second-generation unit root test is applied, and the results are summarized in the same table. According to the stationarity test results, the capital variable is stationarity at the level and the other variables are stationarity at the first difference.

Table 1. Cross-Sectional Dependency and Unit Root Test Results

\begin{tabular}{|c|c|c|c|c|c|}
\hline \multirow[b]{2}{*}{ Series } & \multicolumn{2}{|c|}{ Level } & \multicolumn{2}{|c|}{$1^{\text {st }}$ difference } & \multirow[b]{3}{*}{ CD Test } \\
\hline & $\mathbf{q}$ & $q, t$ & $\mathbf{q}$ & $q, t$ & \\
\hline TFP & -0.959 & -1.596 & $-4.331^{* * *}$ & $-5.204^{* * *}$ & \\
\hline $\mathrm{FE}$ & -1.542 & -1.776 & $-4.576^{* * *}$ & $-4.759^{* * *}$ & Stat.: 2.399 \\
\hline REE & -1.344 & -2.617 & $-5.879^{* * *}$ & $-6.045^{* * *}$ & Prob.: 0.016 \\
\hline $\mathrm{K}$ & $-2.328^{* *}$ & $-2.957^{\text {*** }}$ & $-5.458^{* * *}$ & $-5.497^{* * *}$ & \\
\hline $\mathrm{L}$ & -1.991 & -1.917 & $-4.421^{* * *}$ & $-5.691^{* * *}$ & \\
\hline
\end{tabular}

Following the unit root test, a second generation cointegration test, Westerlund (2007) is adopted. Test results are presented in Table 2. When Table 2 is examined, the existence of a strong cointegration relationship between the series in the long run draws attention. This result is laid the groundwork for the next step to move on to the coefficient estimation stage, which reveals the direction and size of the effect of explanatory variables on the dependent variable.

Table 2. Cointegration Test Results

\begin{tabular}{lccc}
\hline Statistic & Value & Z-value & P-value \\
\hline $\mathrm{Gt}$ & -3.769 & -6.042 & 0.000 \\
$\mathrm{Ga}$ & -3.555 & -2.000 & 0.000 \\
$\mathrm{Pt}$ & -1.666 & -1.555 & 0.000 \\
$\mathrm{~Pa}$ & -9.222 & -5.333 & 0.000 \\
\hline
\end{tabular}

Long run estimation results are given in Table 3. Accordingly, while renewable energy consumption has an increasing effect on TFP in the long run (as seen in Rath et al., 2019; 
Tugcu, 2013), the positive effect of fossil fuel energy consumption is statistically insignificant. On the other hand, it is a fact that this effect of renewable energy is quite small. An increase in renewable energy consumption increases the total factor productivity by about 0.007 percent in the long run. This result is a positive reflection of the environmental and technological contributions of turning to renewable energy sources in these countries on total factor productivity. Another contribution to the TFP growth is provided by capital accumulation. That is, an increase in gross capital formation increases TFP by about 0.09 percent. On the other hand, another result is that an increase in the total labor force reduces TFP.

Table 3. Long run coefficient estimation results (Dep. Var.=TFP)

\begin{tabular}{lccc}
\hline Statistic & Coefficient & Driscoll/Kraay Std. Err. & P-value \\
\hline FE & 0.027 & 0.017 & 0.125 \\
REE & 0.007 & 0.002 & 0.003 \\
K & 0.092 & 0.009 & 0.000 \\
L & -0.228 & 0.017 & 0.000 \\
C & 0.000 & 0.002 & 0.786 \\
\hline
\end{tabular}

The results revealed that renewable energy consumption and capital formation are determinants of TFP growth in G20 countries. In addition, although the effect of renewable energy consumption is relatively small, it can be said that strengthening this positive effect has a significant potential benefit in TFP growth. Moreover, it emerges that in these countries it is more critical to strengthen the labor force in quality rather than increase in quantity. At this point, the contribution of the increase in capital formation and the widespread use of renewable energy to productivity becomes meaningful.

\section{Conclusion}

In this study, the effect of renewable and non-renewable energy consumption on TFP is analyzed for G20 countries. For this purpose, the Driscoll-Kraay standard errors method is applied for the 1990-2015 data period. In addition, labor and capital variables are included in the model as control variables. The results showed that renewable energy consumption and capital formation contributed to TFP growth in these countries. The result for renewable energy consumption is in line with Tugcu, (2013), Rath et al. (2019) and Sohag et al. (2021). While there is an insignificant effect of fossil fuel energy consumption on TFP is found (as seen in Sohag et al., 2021), the reducing effect of total labor force is revealed.

Considering that energy is an indispensable element of production, the results achieved in terms of TFP bring energy efficiency to the agenda. This is a more comprehensive measure than simply reducing energy use. At this point, it is important to focus on both low cost and environmentally friendly energy sources. Renewable energy consumption is critical to ensure environmental efficiency, and empirical results are in line with this view. However, the limited positive impact of renewable energy consumption on TFP in these countries suggests that this energy consumption is relatively costly. Accordingly, reducing renewable energy costs should be one of the policy priorities of these countries. Extending government subsidies to renewable energy generation can be adopted as an alternative to reduce costs. In addition, an environmentally friendly and energy-saving technological production infrastructure should be 
established. The positive effect of capital formation on TFP can be considered as an advantage for the G20 countries in this respect. Thus, it is critical for TFP growth in the long run to implement policies for developments that support energy efficiency while turning to renewable energy sources. Moreover, the adoption of such practices by the world's largest economies may change the balance on a global scale in this direction.

The main policy implications can be stated as follows: i) It is known that the energy consumption levels of the G20 countries are quite large. Therefore, the energy composition of these countries is of global scale. In line with this importance, the priority of these countries should be finance renewable energy sources. Especially, providing support to green industries should be one of the main policies of countries. ii) Renewal of energy systems in these countries is another of the basic policies. Accordingly, new energy systems should have the infrastructure to adopt to the changing energy composition as much as possible. This priority should be considered, for example, in the installation of power plants, the production of motor vehicles, and the development of industrial production technologies. iii) Energy transformation projects should be emphasized within the G20, and cooperation between countries should be guaranteed in this process, depending on a number of rules and sanctions. iv) In addition, reducing technology costs is an important measure at the point of popularizing the use of environmentally friendly energy resources to increase energy efficiency. For this, energy-saving technologies should be used in energy production and consumption processes.

This study especially revealed the importance of renewable energy for TFP. More indepth analyzes of the subject in future studies may contribute to the development of relevant literature. Both current methodological approaches and different types of energy may be included in the analyzes for this purpose.

\section{Researchers' Contribution Rate Statement}

Since, this study is a single-authored, the researcher's contribution to the study is one hundred percent.

\section{Conflict of Interest Statement}

There is no potential conflict of interest in this study. 


\section{References}

Acaravc1, A., Erdogan, S. and Akalin, G. (2015). The electricity consumption, real income, trade openness and foreign direct investment: The empirical evidence from Turkey. International Journal of Energy Economics and Policy, 5(4), 1050-1057. Retrieved from https://econjournals.com/index.php

Aqeel, A. and Butt, M. S. (2001). The relationship between energy consumption and economic growth in Pakistan. Asia-Pacific Development Journal, 8(2), 101-110. Retrieved from https://www.unescap.org/knowledge-products-series/asia-pacific-development-journal

Baz, K., Cheng, J., Xu, D., Abbas, K., Ali, I., Ali, H. and Fang, C. (2021). Asymmetric impact of fossil fuel and renewable energy consumption on economic growth: A nonlinear technique. Energy, 226, 120357. https://doi.org/10.1016/j.energy.2021.120357

Bhattacharya, M., Paramati, S. R., Ozturk, I. and Bhattacharya, S. (2016). The effect of renewable energy consumption on economic growth: Evidence from top 38 countries. Applied Energy, 162, 733-741. https://doi.org/10.1016/j.apenergy.2015.10.104

Chen, C., Pinar, M. and Stengos, t. (2020). Renewable energy consumption and economic growth nexus: Evidence from a threshold model. Energy Policy, 139, 111295. https://doi.org/10.1016/j.enpol.2020.111295

Cheng, B. S. and Lai, T. W. (1997). An investigation of co-integration and causality between energy consumption and economic activity in Taiwan. Energy Economics, 19(4), 435-444. https://doi.org/10.1016/S0140-9883(97)01023-2

Dogan, E. (2014). Energy consumption and economic growth: Evidence from low-income countries in Sub-saharan Africa. International Journal of Energy Economics and Policy, 4(2), 154-162. Retrieved from http: www.econjournals.com

Driscoll, J. C. and Kraay, A. C. (1998). Consistent covariance matrix estimation with spatially dependent panel data. The Review of Economics and Statistics, 80(4), 549-560. Retrieved from https://www.jstor.org/

Fang, Z. and Chang, Y. (2016). Energy, human capital and economic growth in Asia Pacific CountriesEvidence from a panel cointegration and causality analysis. Energy Economics, 56, 177-184. https://doi.org/10.1016/j.eneco.2016.03.020

Glasure, Y. U. (2002). Energy and national income in Korea: Further evidence on the role of omitted variables. Energy Economics, 24, 355-365. https://doi.org/10.1016/S0140-9883(02)00036-1

Hamilton, J. D. (1983). Oil and the macroeconomy since World War II. The Journal of Political Economy, 91(2), 228-248. Retrieved from https://www.journals.uchicago.edu/toc/jpe

Im, K. S., Pesaran, M. H. and Shin, Y. (2003). Testing for unit roots in heterogeneous panels. Journal of Econometrics, 115(1), 53-74. https://doi.org/10.1016/S0304-4076(03)00092-7

Isaksson, A. (2007). Determinants of total factor productivity: A literature review (UNIDO Research and Statistics Branch Staff Working Paper No. 02/2007). Retrieved from http://www.rrojasdatabank.info/87573_determinants_of_total_factor_productivity.pdf

Isik, C., Dogru, E. and Turk, E. S. (2018). A nexus of linear and non-linear relationship between tourism demand, renewable energy consumption, and economic growth: Theory and evidence. International Journal of Tourism Research, 20, 38-49. https://doi.org/10.1002/jtr.2151

Kraft, J. and Kraft, A. (1978). On the relationship between energy and GNP. Journal of Energy Development, 3, 401-403. Retrieved from https://www.jstor.org/

Ladu, M. G. and Meleddu, M. (2014). Is there any relationship between energy and TFP (total factor productivity)? A panel d-cointegration approach for Italian regions. Energy, 75, 560-567. https://doi.org/10.1016/j.energy.2014.08.018

Lin, B. and Xu, B. (2020). How does fossil energy abundance affect China's economic growth and $\mathrm{CO}_{2}$ $\begin{array}{lllll}\text { emissions? Science of The Total Environment, } & 719, & 137503 .\end{array}$ https://doi.org/10.1016/j.scitotenv.2020.137503 
Masih, A. M. M. and Masih, R. (1996). Energy consumption, real income and temporal causality: Results from a multi-country study based on cointegration and error-correction modelling techniques. Energy Economics, 18(3), 165-183. https://doi.org/10.1016/0140-9883(96)00009-6

Mehrara, M. (2007). Energy consumption and economic growth: The case of oil exporting countries. Energy Policy, 35, 2939-2945. https://doi.org/10.1016/j.enpol.2006.10.018

Moghaddasi, R. and Pour, A. A. (2016). Energy consumption and total factor productivity growth in Iranian agriculture. Energy Reports, 2, 218-220. https://doi.org/10.1016/j.egyr.2016.08.004

Narayan, P. K. and Narayan, S. (2010). Carbon dioxide emissions and economic growth: Panel data evidence from developing countries. Energy Policy, 38(1), 661-666. https://doi.org/10.1016/j.enpol.2009.09.005

Nasreen, S. and Anwar, S. (2014). Causal relationship between trade openness, economic growth and energy consumption: A panel data analysis of Asian countries. Energy Policy, 69, 82-91. https://doi.org/10.1016/j.enpol.2014.02.009

Ocal, O. and Aslan, A. (2013). Renewable energy consumption-economic growth nexus in Turkey. Renewable and Sustainable Energy Reviews, 28, 494-499. http://dx.doi.org/10.1016/j.rser.2013.08.036

Ouedraogo, N. S. (2013). Energy consumption and economic growth: Evidence from the economic community of West African States (ECOWAS). Energy Economics, 36, 637-647. https://doi.org/10.1016/j.eneco.2012.11.011

Ozcan, B. and Ozturk, I. (2019). Renewable energy consumption-economic growth nexus in emerging countries: A bootstrap panel causality test. Renewable and Sustainable Energy Reviews, 104, 3037. https://doi.org/10.1016/j.rser.2019.01.020

Paul, S. and Bhattacharya, R. N. (2004). Causality between energy consumption and economic growth in India: A note on conflicting results. Energy Economics, 26, 977-983. https://doi.org/10.1016/j.eneco.2004.07.002

Payne, J. E. (2009). On the dynamics of energy consumption and output in the US. Applied Energy, 86(4), 575-577. https://doi.org/10.1016/j.apenergy.2008.07.003

Pesaran, M. H. (2004). General diagnostic tests for cross section dependence in panels (IZA Discussion Paper No. 1240). Retrieved from https://link.springer.com/content/pdf/10.1007/s00181-02001875-7.pdf

Pesaran, M. H. (2007). A simple panel unit root test in the presence of cross-section dependence. Journal of Applied Econometrics, 22(2), 265-312. https://doi.org/10.1002/jae.951

Rahman, M. S., Shahari, F., Rahman, M. and Noman, A. H. M. (2017). The interdependent relationship between sectoral productivity and disaggregated energy consumption in Malaysia: Markov Switching approach. Renewable and Sustainable Energy Reviews, 67, 752-759. https://doi.org/10.1016/j.rser.2016.09.016

Rath, B. N., Akram, V., Bal, D. P. and Mahalik, M. K. (2019). Do fossil fuel and renewable energy consumption affect total factor productivity growth? Evidence from cross-country data with policy insights. Energy Policy, 127, 186-199. https://doi.org/10.1016/j.enpol.2018.12.014

Shahbaz, M., Zkaria, M., Shahzad, S. J. H. and Mahalik, M. K. (2018). The energy consumption and economic growth nexus in top ten energy-consuming countries: Fresh evidence from using the quantile-on-quantile approach. Energy Economics, $282-301$. https://doi.org/10.1016/j.eneco.2018.02.023

Şimşek, N. (2011). Environmental efficiency and total factor productivity of Turkey: A comparative analysis. Ege Academic Review, 11(3), 379-396. Retrieved from https://dergipark.org.tr/tr/pub/eab

Sohag, K., Chukavina, K. and Samargandi, N. (2021). Renewable energy and total factor productivity in OECD member countries. Journal of Cleaner Production, 296, 126499. https://doi.org/10.1016/j.jclepro.2021.126499 
Ekonomi, Politika \& Finans Araştırmaları Dergisi, 2021, 6(Özel Say1): 54-64

Journal of Research in Economics, Politics \& Finance, 2021, 6(Special Issue): 54-64

Tugcu, C. T. (2013). Disaggregate energy consumption and total factor productivity: A cointegration and causality analysis for the Turkish economy. International Journal of Energy Economics and Policy, 3(3), 307-314. Retrieved from http: www.econjournals.com

Tugcu, C. T. and Tiwari, A. K. (2016). Does renewable and/or non-renewable energy consumption matter for total factor productivity (TFP) growth? Evidence from the BRICS. Renewable and Sustainable Energy Reviews, 65, 610-616. https://doi.org/10.1016/j.rser.2016.07.016

Wang, E. Z. and Lee, C. C. (2021). The impact of clean energy consumption on economic growth in China: Is environmental regulation a curse or a blessing? International Review of Economics \& Finance, 77, 39-58. https://doi.org/10.1016/j.iref.2021.09.008

Westerlund, J. (2007). Testing for error correction in panel data. Oxford Bulletin of Economics and Statistics, 69(6), 709-748. https://doi.org/10.1111/j.1468-0084.2007.00477.x

Yu, E. S. H. and Jin, J. C. (1992). Cointegration tests of energy consumption, income, and employment. Resources and Energy, 14(3), 259-266. https://doi.org/10.1016/0165-0572(92)90010-E 